\title{
Correlation between blood, physiological and behavioral parameters in beef calves under heat stress
}

\author{
Won Seob Kim ${ }^{1,2}$, Jae-Sung Lee ${ }^{1,2}$, Seung Woo Jeon ${ }^{1}$, Dong Qiao Peng ${ }^{1,2}$, Young Shin Kim, \\ Mun Hee Bae ${ }^{1}$, Yong Ho Jo ${ }^{1,2}$, and Hong Gu Lee ${ }^{1,2, *}$
}

\begin{abstract}
* Corresponding Author: Hong Gu Lee Tel: +82-2-450-0523, Fax: +82-2-455-1044, E-mail: hglee66@konkuk.ac.kr
\end{abstract}

'Department of Animal Science and Technology, Konkuk University, Seoul 05029, Korea ${ }^{2}$ An Team of Educational Program for Specialists in Global Animal Science, Brain Korea 21 Plus Project, Konkuk University, Seoul 05029, Korea

ORCID

Won Seob Kim

https://orcid.org/0000-0002-0234-5665 Jae-Sung Lee

https://orcid.org/0000-0001-8940-9862 Seung Woo Jeon

https://orcid.org/0000-0001-6210-855X Dong Qiao Peng

https://orcid.org/0000-0002-0408-0381

Young Shin Kim

https://orcid.org/0000-0003-0257-3796

Mun Hee Bae

https://orcid.org/0000-0001-7815-9597

Yong Ho Jo

https://orcid.org/0000-0002-9842-5765

Hong Gu Lee

https://orcid.org/0000-0002-0679-5663

Submitted Jul 22, 2017; Revised Oct 15, 2017; Accepted Nov 9, 2017
Objective: The performance, health, and behaviour of cattle can be strongly affected by climate. The objective of this study was to determine the effect of heat stress on blood parameters, blood proteins (haptoglobin [Hp]; heat shock protein 70 [HSP70]), rectal temperature (RT), heart rate (HR) and rumination time in Korean native beef calves.

Methods: Thirty-two Korean native beef calves were randomly assigned to 8 groups with 4 animals per group. They were kept in environmental condition with temperature-humidity index (THI) ranging from 70.01 to 87.72 in temperature-humidity controlled chamber for 7 days.

Results: Their HR, RT, and serum cortisol and HSP70 levels were increased $(\mathrm{p}<0.05)$ in high THI compared to those at low THI. But, serum Hp level was decreased $(\mathrm{p}<0.05)$ in high THI compared to these at low THI. In addition, HR, RT, serum cortisol and HSP70 were positively correlated with THI $\left(\mathrm{R}^{2}=0.8368, \mathrm{p}<0.01 ; \mathrm{R}^{2}=0.6162, \mathrm{p}<0.01 ; \mathrm{R}^{2}=0.581, \mathrm{p}<0.01 ; \mathrm{R}^{2}=0.2241\right.$, $\mathrm{p}=0.0062$, respectively). There was also positive association between $\mathrm{HR}$ and cortisol $\left(\mathrm{R}^{2}=\right.$ $0.4697, \mathrm{p}<0.01)$. Similarly, $\mathrm{RT}$ and cortisol were positively associated $\left(\mathrm{R}^{2}=0.4581, \mathrm{p}<0.01\right)$. But, THI and HR were negatively correlated with $\operatorname{Hp}\left(R^{2}=0.2157, p=0.02 ; R^{2}=0.3362, p=\right.$ 0.003). Hematology and metabolites results were different among treatment groups. Standing position was higher $(\mathrm{p}<0.05)$ in the high THI group compared to that in the low THI group. Conclusion: Based on these results, it can be concluded that HR, RT, blood parameters (Cortisol, HSP70, Hp) and standing position are closely associated with heat stress. These parameters can be consolidated to develop THI chart for Korean native beef calves.

Keywords: Bovine; Climatic Chamber; Homeostasis; Metabolism

\section{INTRODUCTION}

Heat stress causes economic losses because it decreases milk yield and growth performance in both dairy and beef cattle [1]. Since the climate of South Korea is gradually changing to subtropical, economic due to heat stress loss is also increasing, especially during summer. Therefore, developing optimal environmental factors can be used to prevent heat stress and reduce economic losses. Temperature humidity index (THI) is an indicator of heat stress. It can be used to estimate the cooling requirements for dairy cattle in order to improve productivity and efficiency of management strategies [2]. Previous studies have shown that heart rate (HR), respiratory rate and rectal temperature (RT), and milk production in dairy cattle can be affected by stress [3]. However, these previous studies have focused on physiological index through external performance. They do not reflect the response of internal performances, specially energy metabolism, hormone and blood parameters. Calves are especially sensitive to external environment. Therefore, more precise and a variety of stress parameters should be monitored. The effect of heat stress during calf stage on the beef cattle industry 
might have indirect economic losses due to decreased growth performance and increased disease outbreaks [4]. Although several reviews have been focused on the effect of heat stress on dairy cows, such effect on beef calves has not been widely studied [5]. In addition, behavioural and physiological indicators of stress related to environment, especially temperature and humidity, have not been studied in Korean native beef calves.

Therefore, the objective of this study was determine the most important parameters related to heat stress to develop a more accurate THI chart in Korean native beef calves. In order to achieve this goal, we measured blood metabolites [6] and behaviour [7] parameters related to heat stress.

\section{MATERIALS AND METHODS}

\section{Animals}

Eight different experiments were done during the study period. Thirty-two Korean native male beef calves ( 6 months age, $204.5 \pm 6.79 \mathrm{~kg}$ ) were used for each experiment (four calves per experiment). The four calves were housed in an environmentally controlled individual with 2 chambers (the two calves were housed in a chamber seperated into two parts). All experimental procedures were in accordance with the "Guidelines for Care and Use of Experimental Animals of Konkuk University (KU16054)".

\section{Climatic chamber details}

The size of the climatic chamber was $2.5 \times 2.5 \times 3 \mathrm{~m}$ (length, width, and height, respectively). The chamber had ambient temperature of $22^{\circ} \mathrm{C}$ to $34^{\circ} \mathrm{C}$ and relative humidity (RH) ranging from $60 \%$ to $80 \%$. The chamber has controllable temperature and humidity regulators to maintain the ideal temperature and humidity from 0900 to 1900 per the requirement of the experiment time with a 10:14 light:dark cycle. The climatic chamber was individually separated to contain animals so that feed and water could be offered on an individual basis. Animals were allocated to each space of chamber and acclimatized to the chambers in a thermoneutral environment condition for 3 days. Consequently, calves were exposed to specified experimental environment for 4 days.

\section{Management conditions and treatments}

The study was conducted to assess the impact of simulated near-natural heat stress conditions in individual climatic chamber on the adaptive capability of Korean native male beef calves. The study was conducted in eight different experiments. It was designed to have four levels of dry bulb temperature $\left(22^{\circ} \mathrm{C}\right.$ to $\left.34^{\circ} \mathrm{C}\right)$ and two levels of humidity (60\% to $\left.80 \%\right)$. During thrmoneutral period, all animals were housed in constant thermoneutral contitions $\left(22^{\circ} \mathrm{C}, 60 \%\right.$, THI $=68.61$ with a $10: 14$ light:dark cycle). During heat stress period, all animals were housed in constant heat condition $\left(23^{\circ} \mathrm{C}, 60 \%\right.$, THI $=70.01$; $23^{\circ} \mathrm{C}, 80 \%$, THI $=71.71 ; 26^{\circ} \mathrm{C}, 60 \%$, THI $=74.22 ; 26^{\circ} \mathrm{C}, 80 \%$, $\mathrm{THI}=76.51 ; 30^{\circ} \mathrm{C}, 60 \%$, $\mathrm{THI}=79.84 ; 30^{\circ} \mathrm{C}, 80 \%$, $\mathrm{THI}=82.92$; $33^{\circ} \mathrm{C}, 60 \%$, THI $=84.05 ; 33^{\circ} \mathrm{C}, 80 \%$, THI $=87.72$ with a $10: 14$ light:dark cycle. These conditions were set by the THI range according to the environmental conditions of South Korea. Ambient temperature and $\mathrm{RH}$ inside the chamber were recorded at intervals of $1 \mathrm{~s}$ using two sensors (SHT7x, Sensirion AG, Laubisruetistrasse 508712 Staefa ZH, Switzerland). THI was calculated using dry bulb temperature $\left(\mathrm{Tdb},{ }^{\circ} \mathrm{F}\right)$ and $\mathrm{RH}$ using the formula of Tdb- $(0.55-(0.55 \times \mathrm{RH} / 100) \times(\mathrm{Tdb}-58)$ according to a previous study [8]. These animals were provided free access to feed and water which were, supplied at $0900 \mathrm{~h}$. The residues of both feed and water were recorded on the next day $(0900 \mathrm{~h})$. The diet used in this study was composed of $40 \%$ roughage (Phleum pretense L.) and $60 \%$ concentrate. Their chemical compositions are shown in Table 1 . These calves were subjected to heat stress by exposing them to different environments (THI ranging between 70.01 and 87.72) from 0900 to 1900.

\section{Physiological parameters under heat stress}

Feeds and water were given to calves four times a day. Feed and water remained were measured in the next morning before feeding $(0800 \mathrm{~h})$. During the acclimation period and experiment period, water intake (WI) and feed intake (FI) were measured daily. Entire behaviour was recorded with a video system (0900 to $1900 \mathrm{~h}$ ). The HR was determined by measuring the beat per minute of the heart using a stethoscope (1100 h). The RT was measured on the 2 nd day and the last day $(1100 \mathrm{~h})$ during the experimental period.

\section{Blood and behaviour parameters under heat stress}

Blood samples of each calves were obtained at $1100 \mathrm{~h}$ from jugular venepuncture into non-heparinized vacutainers (20 mL; Becton-Dickinson, Belliver Industrial Estate, PL6 7BP, Plymouth, UK) and ethylenediaminetetraacetic acid-treated vacutainers ( $4 \mathrm{~mL}$; Becton-Dickinson, Franklin Lakes, NJ, USA) on the initial day and the final day of each experiment. Serum samples were obtained from blood samples after centrifugation at $2,700 \times \mathrm{g}$ at $4^{\circ} \mathrm{C}$ for $15 \mathrm{~min}$. Serum was transferred to 1.5-mL tube (Eppendorf AG, Hamburg, Germany) and kept

Table 1. Chemical compositions of diets provided to the beef calves

\begin{tabular}{lcc}
\hline Ingredient (\%) & Concentrates & Roughage (Timothy) \\
\hline \% of dry matter & & \\
Crude protein & 14.59 & 8.11 \\
Ether extract & 3.47 & 1.51 \\
Crude fiber & 9.55 & 29.51 \\
Crude ash & 6.38 & 6.32 \\
Calcium & 1.24 & 0.39 \\
Phosphorus & 0.44 & 0.2 \\
\hline
\end{tabular}


at $-80^{\circ} \mathrm{C}$ until analysis. Whole blood samples (White blood cell; Lymphocyte [Lym]) were determined as haematological traits using VetScan HM2 (Diamond Diagnostics, Abaxix Inc., Holliston, MA, USA). Analytical reagents for measuring glucose, glutamic oxaloacetic transaminase (GOT), and glutamic pyruvate transaminase (GPT) levels were purchased from JW Medical (Seoul, Korea). The analytical reagent for measuring non-esterified fatty acid (NEFA) was purchased from Wako Pure Chemical (Osaka, Japan). All these parameters were analysed using an automated chemistry analyser (Hitachi 7180, Tokyo, Japan). Serum cortisol, haptoglobin (Hp), heat shock protein 70 (HSP70) level were determined using a commercial Bovine ELISA test kit (Life Diagnostics, Inc; Neo Group, Inc; Endocrine Technologies, Inc, West Chester, PA; Boston, MA; Newark, CA, USA). Behaviour patterns were recorded using two cameras (SNV-7080R, Hanwha Techwin, Changwon, Korea). The frequency of ruminant, lying, and standing on the 3rd day (0900 to $1900 \mathrm{~h}$ ) was calculated.

\section{Statistical analysis}

All data are expressed as means \pm standard error of mean. Data were analyzed using the MIXED procedure of JMP 5.0 (SAS Institute Inc., Cary, NC, USA). The model included THI as fixed variable and physiological, blood and behavior traits as random variables. When significance was found, a TukeyKramer honestly significant difference for mean comparisons was performed. Differences were considered statistically significant if $\mathrm{p}$-value was less than $0.05(\mathrm{p}<0.05)$. Relationships between levels of THI and parameters (HR, RT, cortisol) were tested by regression (Microsoft Excel 2013; Microsoft, Redmond, WA, USA)

\section{RESULTS}

\section{Physiological responses}

The HR was significantly $(\mathrm{p}<0.05)$ higher at THI of 76.51 to 87.72 than that at THI of 70.01 (Table 2). Similar pattern was found for RT. Furthermore, there were significantly $\left(\mathrm{R}^{2}=\right.$ $0.8368, \mathrm{p}<0.01)$ positive association between THI and HR (Figure $1 \mathrm{~A})$. THI and RT also showed significantly $\left(\mathrm{R}^{2}=0.6162\right.$, $\mathrm{p}<0.01$ ) positive association (Figure $1 \mathrm{~B}$ ). WI was significantly
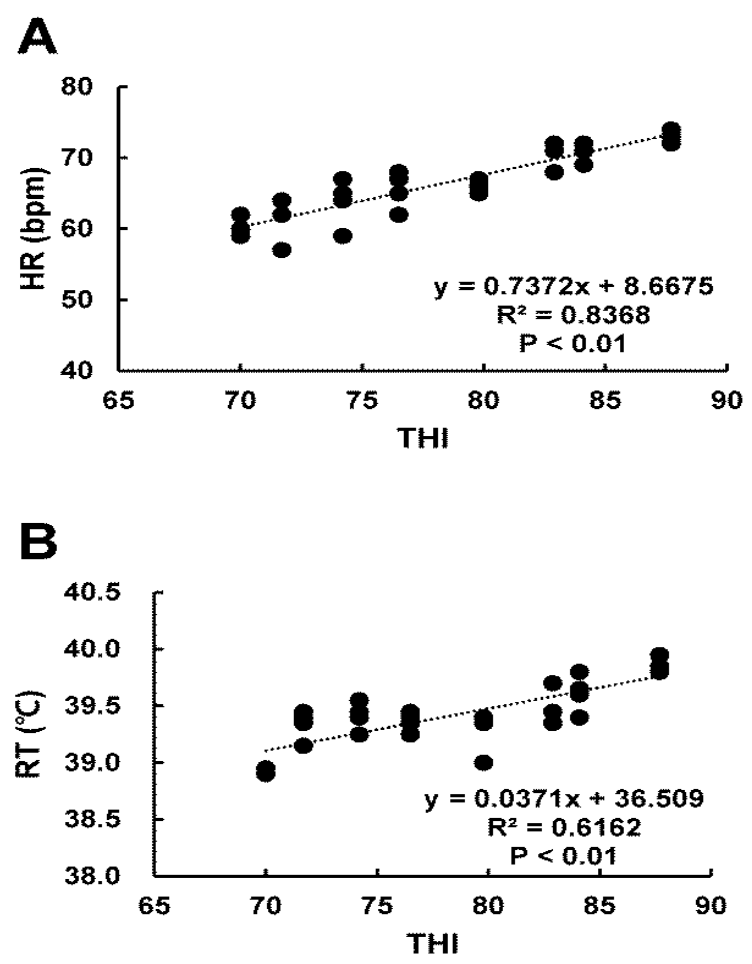

Figure 1. Relationship between heart rate (HR), rectal temperature (RT), and temperature humidity index (THI) under heat stress. (A) HR and (B) RT were measured on the 2 nd day and the last day $(1100 \mathrm{~h})$ during the experimental period. HR and RT were increased at high THI compared to those at low THI ( $R^{2}$ $=0.8368, p<0.01 ; R^{2}=0.6162, p<0.01$, respectively).

$(\mathrm{p}<0.05)$ increased at THI from 82.92 to 84.05 compared to that at THI 74.22 (Table 2).

\section{Stress and blood parameters}

Stress indicator; serum cortisol level was significantly $(\mathrm{p}<0.05)$ higher at THI of 84.05 to 87.72 than that at THI of 70.01 to 82.92 (Table 3). There were significantly $\left(\mathrm{R}^{2}=0.581, \mathrm{p}<0.01\right)$ positive association between THI and cortisol (Figure 2) and between HR and cortisol $\left(\mathrm{R}^{2}=0.4697, \mathrm{p}<0.01\right)$ (Figure $3 \mathrm{~A}$ ). RT and cortisol also had significantly $\left(\mathrm{R}^{2}=0.4581, \mathrm{p}<0.01\right)$ positive association (Figure 3B). Blood protein indicators; HSP70 level was significantly $(\mathrm{p}<0.05)$ higher at THI of 84.05 to 87.72 compared to that at THI of 74.2 (Table 3). Hp level

Table 2. Relationship between THI and physiological parameters related to heat stress in beef calves

\begin{tabular}{|c|c|c|c|c|c|c|c|c|c|c|}
\hline \multirow{2}{*}{ Parameters } & \multicolumn{8}{|c|}{ THI } & \multirow{2}{*}{ SEM } & \multirow{2}{*}{ p-value } \\
\hline & 70.01 & 71.7 & 74.22 & 76.51 & 79.84 & 82.92 & 84.05 & 87.72 & & \\
\hline Heart rate (beat/min) & $60.3^{e}$ & $61.2^{\text {de }}$ & $63.8^{\text {cde }}$ & $65.5^{\text {cd }}$ & $66.3^{b c}$ & $70.5^{\mathrm{ab}}$ & $71.0^{\mathrm{ab}}$ & $73.0^{\mathrm{a}}$ & 1.06 & $<0.001$ \\
\hline Rectal temperature $\left({ }^{\circ} \mathrm{C}\right)$ & $38.9^{d}$ & $39.3^{b c}$ & $39.4^{\mathrm{bc}}$ & $39.4^{\mathrm{bc}}$ & $39.3^{c}$ & $39.5^{b c}$ & $39.6^{\mathrm{ab}}$ & $39.9^{\mathrm{a}}$ & 0.06 & $<0.001$ \\
\hline Feed intake $(\mathrm{kg} / \mathrm{d})$ & 2.4 & 2.0 & 1.7 & 2.2 & 2.2 & 1.9 & 1.5 & 1.7 & 0.24 & 0.150 \\
\hline Water intake $(\mathrm{L} / \mathrm{d})$ & $23.4^{\mathrm{ab}}$ & $24.8^{\mathrm{ab}}$ & $20.6^{b}$ & $24.8^{\mathrm{ab}}$ & $27.8^{\mathrm{ab}}$ & $31.5^{\mathrm{a}}$ & $31.8^{\mathrm{a}}$ & $26.8^{\mathrm{ab}}$ & 1.98 & 0.006 \\
\hline
\end{tabular}

THI, temperature humidity index; SEM, standard error of the mean.

$a, b, c, d, e$ Values within a row with different superscripts are significantly different according to Tukey's test at $p<0.05$. 
Table 3. Relationship between THI and blood parameters related to heat stress in beef calves

\begin{tabular}{|c|c|c|c|c|c|c|c|c|c|c|}
\hline \multirow{2}{*}{ Parameters } & \multicolumn{8}{|c|}{ THI } & \multirow{2}{*}{ SEM } & \multirow{2}{*}{$p$-value } \\
\hline & 70.01 & 71.7 & 74.22 & 76.51 & 79.84 & 82.92 & 84.05 & 87.72 & & \\
\hline GOT (U/dL) & $53.5^{\mathrm{abc}}$ & $46.8^{c}$ & $70.7^{\mathrm{a}}$ & $66.3^{\mathrm{ab}}$ & $52.3^{\mathrm{bc}}$ & $58.5^{\mathrm{abc}}$ & $66.5^{\mathrm{ab}}$ & $68.8^{\mathrm{a}}$ & 3.44 & 0.004 \\
\hline GPT (U/dL) & $21.8^{\mathrm{cd}}$ & $19.0^{d}$ & $28.5^{\mathrm{a}}$ & $28.3^{\mathrm{ab}}$ & $23.3^{\text {bcd }}$ & $22.3^{\text {cd }}$ & $27.8^{\mathrm{ab}}$ & $25.0^{\mathrm{abc}}$ & 1.08 & $<0.001$ \\
\hline NEFA $(\mu \mathrm{Eq} / \mathrm{L})$ & $126.3^{\mathrm{b}}$ & $412.6^{\mathrm{a}}$ & $130.6^{b}$ & $238.3^{\mathrm{ab}}$ & $189.0^{\mathrm{ab}}$ & $148.1^{b}$ & $303.7^{\mathrm{ab}}$ & $288.3^{\mathrm{ab}}$ & 52.13 & 0.007 \\
\hline Glucose (mg/dL) & $73.5^{\mathrm{a}}$ & $70.0^{\mathrm{ab}}$ & $65.8^{\mathrm{ab}}$ & $72.5^{\mathrm{a}}$ & $69.5^{\mathrm{ab}}$ & $56.8^{b}$ & $67.8^{\mathrm{ab}}$ & $76.0^{\mathrm{a}}$ & 3.35 & 0.018 \\
\hline WBC $(\mathrm{k} / \mu \mathrm{L})$ & 11.4 & 11.5 & 15.5 & 14.5 & 10.1 & 11.8 & 8.7 & 11.2 & 1.79 & 0.216 \\
\hline 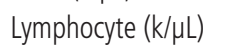 & $5.8^{\mathrm{bc}}$ & $7.7^{\mathrm{abc}}$ & $11.9^{\mathrm{a}}$ & $11.3^{\mathrm{ab}}$ & $6.9^{\mathrm{abc}}$ & $4.9^{c}$ & $5.1^{b c}$ & $7.4^{\mathrm{abc}}$ & 1.31 & 0.007 \\
\hline Platelet $(\mathrm{k} / \mu \mathrm{L})$ & 230.3 & 224.8 & 315.0 & 326.5 & 215.3 & 423.5 & 449.7 & 453.0 & 56.58 & 0.071 \\
\hline Cortisol (ng/mL) & $4.8^{b}$ & $6.4^{b}$ & $6.2^{b}$ & $4.6^{b}$ & $8.4^{b}$ & $7.8^{\mathrm{b}}$ & $15.9^{\mathrm{a}}$ & $17.1^{\mathrm{a}}$ & 1.22 & $<0.001$ \\
\hline Haptoglobin $(\mu \mathrm{g} / \mathrm{mL})$ & $18.7^{\mathrm{ab}}$ & $23.2^{b}$ & $16.5^{\mathrm{abc}}$ & $11.0^{\mathrm{bc}}$ & $14.1^{\mathrm{abc}}$ & $7.4^{c}$ & $14.9^{\mathrm{abc}}$ & $15.2^{\mathrm{abc}}$ & 2.18 & 0.046 \\
\hline HSP70 (ng/mL) & $33.3^{\mathrm{ab}}$ & $47.3^{\mathrm{ab}}$ & $23.8^{b}$ & $31.8^{\mathrm{ab}}$ & $30.2^{\mathrm{ab}}$ & $50.6^{\mathrm{ab}}$ & $54.4^{\mathrm{a}}$ & $54.1^{\mathrm{a}}$ & 5.76 & 0.026 \\
\hline
\end{tabular}

THI, temperature humidity index; SEM, standard error of the mean; GOT, Glutamic oxaloacetic transaminase; GPT, Glutamic pyruvic transaminase; NEFA, non esterified fatty acid; WBC, White blood cell; HSP70, heat shock protein 70.

$a, b, c, d, e$ Values within a row with different superscripts are significantly different according to Tukey's test at $p<0.05$.

was significantly $(\mathrm{p}<0.05)$ lower at THI of 82.9 than that at THI of 70.0 to 71.7 (Table 3). Blood metabolite indicators; GOT and GPT levels were significantly $(\mathrm{p}<0.05)$ increased at THI of 84.05 to 87.72 compared to those at THI of 71.7 (Table 3). NEFA was also significantly $(\mathrm{p}<0.05)$ increased at THI from 84.05 to 87.72 compared to that at THI of 70.01 (Table $3)$. Serum glucose level was significantly $(\mathrm{p}<0.05)$ decreased at THI of 82.92 compared to that of 70.01 to 76.51 (Table 3). Blood haematology indicator Lym was significantly $(\mathrm{p}<0.05)$ lower at THI of 82.92 to 84.05 than that at THI of 74 (Table 3).

\section{Stress and behavior parameters}

Lying position was significantly $(\mathrm{p}<0.05)$ decreased at THI of 74.22 to 87.72 compared to that at THI of 70.01 (Table 4). On the other hand, standing position was significantly $(\mathrm{p}<0.05)$ higher at THI of 74.22 to 87.72 than that at THI of 70.01 (Table 4). Rumination was decreased at high THI compared to that at low THI. However, there was no significant difference

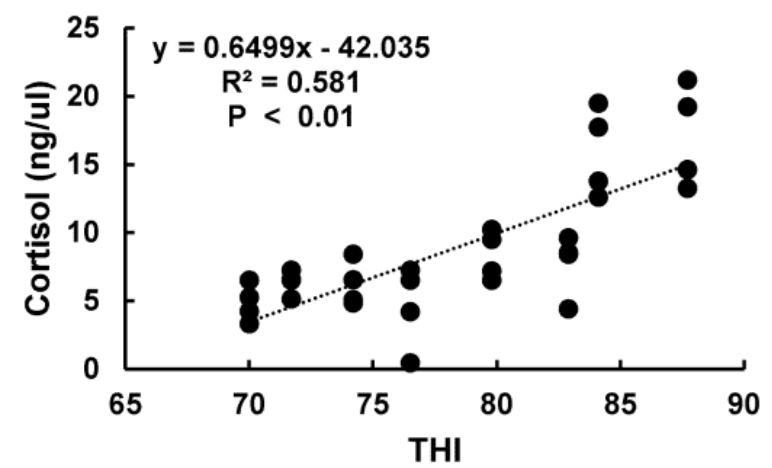

Figure 2. Relationship between serum cortisol level and temperature humidity index (THI) under heat stress. Serum cortisol level was determined using a commercial bovine cortisol ELISA test kit (Life Diagnostics, Inc., West Chester, PA, USA). Serum cortisol level was increased at high THI compared to that at low THI $\left(R^{2}=0.581, p<0.01\right)$. among the 8 groups (Table 4).

\section{DISCUSSION}

This study was conducted to determine the most important parameters related to heat stress to develop a more accurate

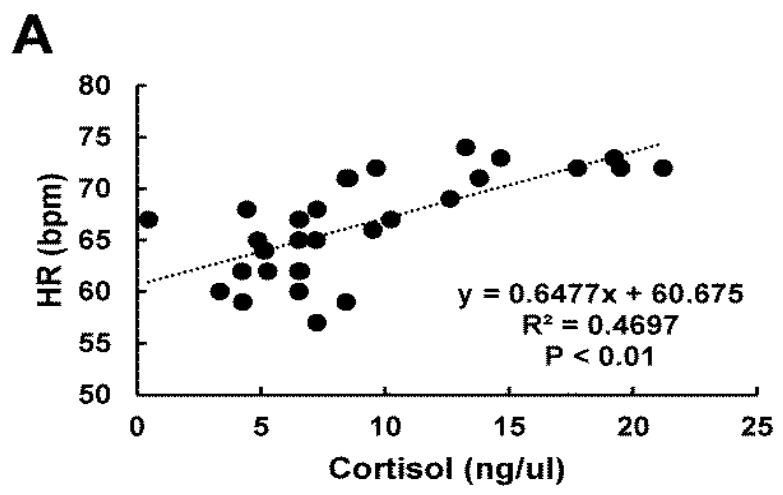

B

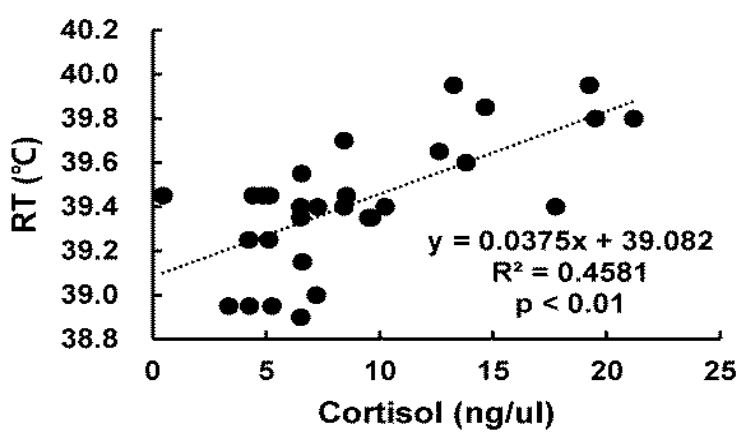

Figure 3. Relationship between heart rate (HR), rectal temperature (RT), and serum cortisol level under heat stress. (A) HR and (B) RT had significantly positive associations with serum cortisol level $\left(R^{2}=0.4697, p<0.01 ; R^{2}=0.4581\right.$, $p<0.01$, respectively). 
Table 4. Relationship between THI and behaviour parameters related to heat stress in beef calves

\begin{tabular}{|c|c|c|c|c|c|c|c|c|c|c|}
\hline \multirow{2}{*}{ Parameters } & \multicolumn{8}{|c|}{ THI } & \multirow{2}{*}{ SEM } & \multirow{2}{*}{ p-value } \\
\hline & 70.01 & 71.7 & 74.22 & 76.51 & 79.84 & 82.92 & 84.05 & 87.72 & & \\
\hline Standing (min/d) & $236^{b}$ & $212^{b}$ & $345^{a}$ & $361^{a}$ & $367^{\mathrm{a}}$ & $368^{\mathrm{a}}$ & $346^{a}$ & $392^{a}$ & 16.09 & $<0.001$ \\
\hline Rumination (The number of times) & 80.0 & 78.0 & 82.7 & 73.3 & 63.7 & 66 & 51.3 & 50.3 & 7.98 & 0.06 \\
\hline
\end{tabular}

$T H I$, temperature humidity index; SEM, standard error of the mean.

a,b Values within a row with different superscripts are significantly different according to Tukey's test at $p<0.05$.

THI chart in Korean native beef calves. All experiments were conducted in temperature and humidity controlled chamber for a more precise study in reference to the research by [9]). Heat stress conditions were examined by setting THI range according to environmental conditions of South Korea.

\section{Physiological responses}

Based on the study results, WI was significantly $(\mathrm{p}<0.05)$ higher at high THI as than that at low THI (Table 2). This result is in accordance with results of previous studies on many different breeds of cattle [10]. Specially, our results showed that WI was increased by $3.3 \mathrm{~L} / \mathrm{d}$ when $\mathrm{THI}$ is increased from 70.01 to 87.72 . The increased WI is also closely associated with body temperature control of ruminants [11]. In general, ruminants carry out body temperature control according to the discharge of body sweat through skin. For this reason, when animals are exposed to high temperature and humidity, physiological sweat discharge is increased to control their body temperature. In this study, we confirmed that this phenomenon beginning from THI of 82.92 in Korean native beef calves (Table 2). The change at this THI level was similar to RT and HR.

Previous studies have shown that the HR and RT are increased by heat stress in growing cattle [6]. Our result showed that HR and RT were closely associated indicators with heat stress. They were most sensitive to heat stress. Therefore, they may be likely to change in Korean native beef calves under heat stress. RT was increased by $0.95^{\circ} \mathrm{C}$ when THI was increased from 70.01 to 87.72 while HR was increased by 12.75 beat/min. In addition, there was significantly $\left(\mathrm{R}^{2}=0.8368, \mathrm{p}<\right.$ 0.01 ) positive association between THI and HR (Figure 1A). Similarly, THI and RT also were significantly $\left(\mathrm{R}^{2}=0.6162\right.$, $\mathrm{p}<$ 0.01 ) and positively associated (Figure 1B). The high correlations among THI, and RT, HR indicate that these indicators could be used as parameters to determine heat stress levels. In general, levels of HR and RT are measured in animals in a variety of environments, with maximum RT and HR indicating severe heat stress [6].

\section{Correlation between physiological responses and blood cortisol}

In this study, there was significantly positive association between serum cortisol level and HR $\left(R^{2}=0.4697, p<0.01\right)$
(Figure 3A). Significantly positive association between serum cortisol level and RT $\left(\mathrm{R}^{2}=0.4697, \mathrm{p}<0.01\right)$ was also found (Figure 3B). An increase in serum cortisol level is closely related to abnormal behaviour of animals such as anxiety and sensitivity $[12,13]$. Reduced animal productivity $[14,15]$ has been utilized as an important indicator for measuring stress levels [16]. HR is correlated with the concentration of blood cortisol. It has been utilized as an index for the regulation of animal body homeostasis [17]. It has been reported that the rise in blood pressure is associated with increased HR [18]. $\mathrm{RT}$ is also an important indicator for homeostasis regulation of body temperature in calves. The positive correlation between cortisol levels and RT might give evidence that there exists a metabolic relationship between cortisol levels and RT. Previous studies have suggested that the concentration of serum cortisol is a sensitive indicator of heat stress and there is a significant correlation between cortisol and RT [19]. Therefore, significant correlation between HR and RT and the concentration of serum cortisol can be used to determine heat stress level as physiological parameters in Korean native beef calves.

\section{Stress and blood parameters}

It has been reported that stress might impair liver function [20]. In the present study, GOT and GPT levels as liver damage markers [21] were increased at high THI. The reduction in serum glucose level at high THI can be explained by different factors, including reduced energy intake as a consequence of reduced FI increased cost for thermoregulation, and negative effect of heat on gluconeogenesis as an endocrine acclimation to hot condition [22]. On the other hand, blood NEFA level was increased at high THI. NEFA and glucose levels have significantly negative correlation [23]. Due to lipolysis, NEFA is released to the bloodstream. It can act as an alternative energy source [24]. Several studies $[25,26]$ have reported the relationships between heat stress and immune cell function in bovine. Regarding lymphocyte function in cows exposed to hot environments, some authors have reported an improvement [27] while others have described an impairment [28]. The reduction of lymphocyte during high THI means that exposure to heat and humidity for $4 \mathrm{~d}$ can decrease the number of viable cells and reduce their responsiveness to mitogens.

The acute phase response with its changes in blood plasma 
composition that react to disturbances of their homeostasis with a set of physiological changes [29]. This responses is associated with changes in lipid and carbohydrate metabolism [30] and in some serum proteins such as acute phase proteins [31]. In our study Hp level was influenced by the experimental period with significantly lower concentratios in high THI. Environmental stressful situations do not always elevate signs of acute stress indicator. Heat shock proteins are beneficial compounds chaperoning damaged cellular molecules by heat stress [32]. The heat shock protein act cognitively in cellular and tissue homeostasis [33] and are released intracellularaly and extracellularly in an inducible form in response to stress [34]. HSP70 level was increased in high THI. Exposure to stressors will induce a heat shock protein response resulting in intra cellular concentrations of HSP70 [35].

\section{Stress and behavior parameters}

Behaviour patterns (standing and lying position) depending on different THI values showed that increasing heat stress relatively increased standing position time. On the other hand, it decreased lying position time (Table 4). Previous studies have already reported behaviour changes in animals in response to high heat stress [36]. Spending more time for standing may allow cows to maximize effective surface area for sensible and insensible heat release from body surfaces, to reduce heat from a warm lying surface, or increase the efficiency of respiration in ruminants [37]. Therefore, under increased THI, animals were affected by heat stress. The positive correlation between THI and standing time was consistent with previous studies. Standing time might be an important indicator of heat stress [38]. In addition, previous studies have suggest that lying position can be increased when animals are provided with shaded environment that reduces heat stress [39].

\section{CONCLUSION}

This study is a correlation analysis among blood, physiologi$\mathrm{cal}$, and behaviour parameters by dividing the level of heat stress using only physiological indices such as HR and RT utilized in THI Chart previously developed for dairy cows. This provides basic data for developing more accurate and precise THI Chart for Korean native beef calves under heat stress.

In conclusion, HR, RT, serum cortisol level, and standing position are closely associated with heat stress based on correlation analysis. These parameters can be consolidated to develop THI chart for Korean native beef calves under heat stress.

\section{CONFLICT OF INTEREST}

We certify that there is no conflict of interest with any financial organization regarding the material discussed in the manuscript.

\section{ACKNOWLEDGMENTS}

This research was supported by the Agricultural Biotechnology Development Program (313020-04), Korea Institute of Planning and Evaluation for Technology in Food, Agriculture, Forestry and Fisheries, Republic of Korea

\section{REFERENCES}

1. St-Pierre N, Cobanov B, Schnitkey G. Economic losses from heat stress by US livestock industries. J Dairy Sci 2003;86: E52-E77.

2. Zimbelman RB. Management strategies to reduce effects of thermal stress on lactating dairy cattle [PhD thesis]. Tucson, AZ, USA: The University of Arizona; 2008.

3. Collier RJ, Hall LW, Rungruang S, Zimbleman RB. Quantifying heat stress and its impact on metabolism and performance. Paper for the 23rd Annual Ruminant Nutrition Symposium; 2012. pp. 74-83.

4. Silanikove N. Effects of heat stress on the welfare of extensively managed domestic ruminants. Livest Prod Sci 2000;67:1-18.

5. Roland L, Drillich M, Klein-Jobstl D, Iwersen M. Invited review: Influence of climatic conditions on the development, performance, and health of calves. J Dairy Sci 2016;99:2438-52.

6. O'Brien MD, Rhoads RP, Sanders SR, Duff GC, Baumgard LH. Metabolic adaptations to heat stress in growing cattle. Domest Anim Endocrinol 2010;38:86-94.

7. Blackshaw JK, Blackshaw A. Heat stress in cattle and the effect of shade on production and behaviour: a review. Anim Prod Sci 1994;34:285-95.

8. Buffington DE, Collazo-Arocho A, Canton GH, et al. Black globe-humidity index (BGHI) as comfort equation for dairy cows. Trans ASAE 1981;24:711-4.

9. Roth Z, Meidan R, Shaham-Albalancy A, Braw-Tal R, Wolfenson D. Delayed effect of heat stress on steroid production in medium-sized and preovulatory bovine follicles. Reproduction 2001;121:745-51.

10. Mader TL, Griffin D. Management of cattle exposed to adverse environmental conditions. Vet Clin North Am Food Anim Pract 2015;31:247-58.

11. Vizzotto EF, Fischer V, Thaler Neto A, et al. Access to shade changes behavioral and physiological attributes of dairy cows during the hot season in the subtropics. Animal 2015;9:155966.

12. Bristow DJ, Holmes DS. Cortisol levels and anxiety-related behaviors in cattle. Physiol Behav 2007;90:626-8.

13. Möstl E, Palme R. Hormones as indicators of stress. Domest Anim Endocrionl 2002;23:67-74.

14. Cooke RF, Bohnert DW, Cappellozza BI, Mueller CJ, Delcurto 
T. Effects of temperament and acclimation to handling on reproductive performance of Bos taurus beef females. J Anim Sci 2012;90:3547-55.

15. Thun R, Kaufmann C, Janett F. The influence of restraint stress on reproductive hormones in the cow. Reprod Domest Anim 1998;33:255-60.

16. Bova TL, Chiavaccini L, Cline GF, et al. Environmental stressors influencing hormones and systems physiology in cattle. Reprod Biol Endocrinol 2014;12:58.

17. Geburt K, Friedrich M, Piechotta M, Gauly M, König von Borstel U. Validity of physiological biomarkers for maternal behavior in cows - A comparison of beef and dairy cattle. Physiol Behav 2015;139:361-8.

18. Price EO, Smith VM, Thos J, Anderson GB. The effects of twinning and maternal experience on maternal-filial social relationships in confined beef cattle. Appl Anim Behav Sci 1986;15:137-46.

19. Follenius M, Brandenberger G, Oyono S, Candas V. Cortisol as a sensitive index of heat-intolerance. Physiol Behav 1982;29: 509-13.

20. Bernabucci U, Ronchi B, Lacetera N, Nardone A. Markers of oxidative status in plasma and erythrocytes of transition dairy cows during hot season. J Dairy Sci 2002;85:2173-9.

21.Panteghini M. Aspartate aminotransferase isoenzymes. Clin Biochem 1990;23:311-9.

22. Abeni F, Calamari L, Stefanini L. Metabolic conditions of lactating Friesian cows during the hot season in the Po valley. 1. Blood indicators of heat stress. Int J Biometeorol 2007;52: 87-96.

23. Shehab-El-Deen MAMM, Fadel MS, Van Soom A, et al. Circadian rhythm of metabolic changes associated with summer heat stress in high-producing dairy cattle. Trop Anim Health Prod 2010;42:1119-25.

24.Leroy JL, Vanholder T, Van Knegsel AT, Garcia-Ispierto I, Bols PE. Nutrient prioritization in dairy cows early postpartum: mismatch between metabolism and fertility? Reprod Domest Anim 2008;43(Suppl 2):96-103.

25.Lacetera N, Bernabucci U, Ronchi B, Scalia D, Nardone A. Moderate summer heat stress does not modify immunological parameters of Holstein dairy cows. Int J Biometeorol 2002;46: 33-7.

26. Kamwanja LA, Chase CC, Gutierrez JA, et al. Responses of bovine lymphocytes to heat shock as modified by breed and antioxidant status. J Anim Sci 1994;72:438-44.

27. Soper FF, Muscoplat CC, Johnson DW. In vitro stimulation of bovine peripheral blood lymphocytes: analysis of variation of lymphocyte blastogenic response in normal dairy cattle. Am J Vet Res 1978;39:1039-42.

28. Elvinger F, Hansen PJ, Natzke RP. Modulation of function of bovine polymorphonuclear leukocytes and lymphocytes by high temperature in vitro and in vivo. Am J Vet Res 1991;52: 1692-8.

29. Gruys E, Toussaint MJM, Niewold TA, Koopmans SJ. Acute phase reaction and acute phase proteins. J Zhejiang Univ Sci B 2005;6:1045-56.

30.Hardardóttir I, Grünfeld C, Feingold KR. Effects of endotoxin and cytokines on lipid metabolism. Curr Opin Lipidol 1994;5: 207-15.

31.Petersen HH, Nielsen JP, Heegaard PMH. Application of acute phase protein measurements in veterinary clinical chemistry. Vet Res 2004;35:163-87.

32. Piñeiro M, Alava M, Lampreave F. Acute phase proteins in different species: a review. 4th European Colloquium on Acute Phase Proteins: Segovia, Spain: Colloquium; 2003. pp. 77-82.

33. de Jong PR, Schadenberg AW, Jansen NJ, Prakken BJ. Hsp70 and cardiac surgery: molecular chaperone and inflammatory regulator with compartmentalized effects. Cell Stress Chaperones 2009;14:117-31.

34. Hecker JG, McGarvey M. Heat shock proteins as biomarkers for the rapid detection of brain and spinal cord ischemia: a review and comparison to other methods of detection in thoracic aneurysm repair. Cell Stress Chaperones 2011;16:11931.

35. Collier RJ, Stiening C, Pollard B, et al. Use of gene expression microarrays for evaluating environmental stress tolerance at the cellular level in cattle. J Anim Sci 2006;84:E1-E13.

36. Allen JD, Hall LW, Collier RJ, Smith JF. Effect of core body temperature, time of day, and climate conditions on behavioral patterns of lactating dairy cows experiencing mild to moderate heat stress. J Dairy Sci 2015;98:118-27.

37. Anderson SD, Bradford BJ, Harner JP, et al. Effects of adjustable and stationary fans with misters on core body temperature and lying behavior of lactating dairy cows in a semiarid climate. J Dairy Sci 2013;96:4738-50.

38.Zahner M, Schrader L, Hauser R, et al. The influence of climatic conditions on physiological and behavioural parameters in dairy cows kept in open stables. Anim Sci 2004;78:139-48.

39. Mitlöhner F, Morrow J, Dailey J, et al. Shade and water misting effects on behavior, physiology, performance, and carcass traits of heat-stressed feedlot cattle. J Anim Sci 2001;79:2327-35. 